\section{Stærkt om og til efterladte efter selvmord}

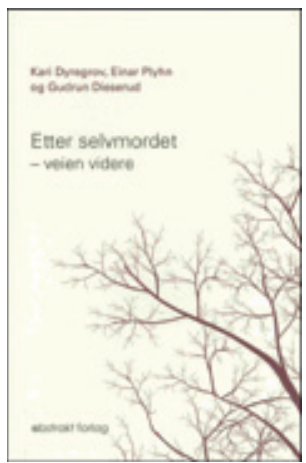

Kari Dyregrov, Einar Plyhn, Gudrun Dieserud Etter selvmordet - veien videre

240 s. Oslo: Abstrakt forlag, 2010

Pris NOK 335

ISBN 978-82-7935-274-7

Mange tabuer står for fald i disse år, også hvad angår døden. Men myter, uvidenhed og tabuisering af selvmord er stadig fremherskende - og blandt andet derfor er den meget veldokumenterede og velskrevne norske bog Etter selvmordet - veien videre særdeles velkommen.

Bogen er et ambitiøst forsøg på både at nå efterladte efter selvmord, deres netværk og de fagfolk, der har selvmord og selvmordsforebyggelse som en del af hverdagen.

Bogens faglige viden bygger på forskning, men den er skrevet $i$ et bevidst lettilgængeligt sprog - og den krydsklipper fagligheden med personlige udsagn fra efterladte. Det er en smuk bog, grafisk overskuelig og godt disponeret, skrevet så kapitlerne kan læses uafhængig af hinanden. Hele tonen, fra først til sidst, er præget af forfatternes ønske om at bidrage til vejen frem. Således er bogen fokuseret på mestringsstrategier, på hvordan det sociale netværk kan støtte, på støtte fra andre efterladte og på fagfolks muligheder for at hjælpe.

Før man kommer til fokus på mestring, gennemgår forfatterne en række af de problemstillinger, der kommer i fokus efter et selvmord, lige fra identificering af liget til sorg- og krisereaktioner, og der sættes fokus på de meget komplicerede sorgreaktioner, som netop efterladte efter selvmord kan have.

Selvmord rammer de efterladte på en måde, som er helt anderledes end andre dødsfald - og det er blandt andet her at selvbebrejdelser, skyld og skam kommer til at fylde meget sammen med spørgsmål som «hvorfor» og «kunne jeg have handlet anderledes?»

En af bogens mange styrker er, at den ikke gør efterladte til ofre, men viser, at de fleste efterladte har et repertoire af mestringsstrategier, ressourcer mange ikke ved de har, før de havner i den ekstreme situation der er at miste ved selvmord.

I et yderst relevant afsnit til de professionelle, fx lægen, præsten, psykiateren, sygeplejersken, socialarbejderen i kommunen, rummer bogen en lang række bud på, hvordan efterladte gerne vil hjælpes, og forfatterne giver en vigtig indføring i de nyeste forståelser af sorg. Også her er det en styrke, at forfatterne hele tiden forholder sig nuanceret til emnet, aldrig sort-hvidt. På den måde lever bogen på fremragende vis op til selve det vanskelige $\mathrm{i}$ at forstå selvmord at der sjældent bare er én forklaring - og derfor må mange efterladte også leve med ubesvarede spørgsmål. Den bør fremover stå på reolen hos alle fagfolk - og være den der rækkes ud efter, når efterladte har brug for hjælp udefra eller hjælp til selvhjælp.

Inger Anneberg

Aarhus Universitet

Danmark

\section{Kollektivt selvmord}

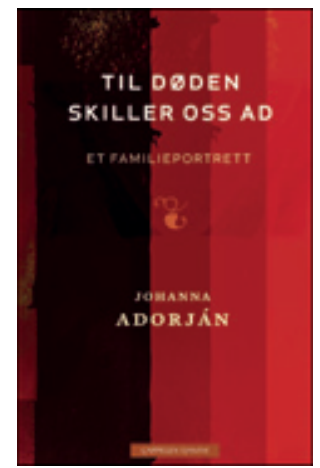

Johanna Adorján

Til døden skiller oss ad

Et familieportrett. 158 s. Oslo: Cappelen

Damm, 2011. Pris NOK 299

ISBN 978-82-02-32577-0

Johanna Adorján er journalist i Frankfurter Allgemeine Sonntagszeitung. Til døden skiller oss ad er hennes første bok. Hun beskriver her hvordan hennes besteforeldre velger å begå kollektivt selvmord fordi bestefaren er uhelbredelig syk og bestemoren ikke orker tanken på å leve videre uten ham. Forfatteren forsøker å trenge inn i sine jødiske besteforeldrenes liv og formidle det til leserne. Vi får høre om bestefarens opphold i konsentrasjonsleir under den annen verdenskrig, om hans karriere som ortoped og medlem av kommunistpartiet i Ungarn etter krigen, og om flukten til Danmark i 1956

Til tross for at forfatteren har en spennende historie å formidle, synes jeg ikke at hun lykkes helt ut $\mathrm{i} a ̊$ fortelle den så godt som den fortjener å bli fortalt. Selv om bakgrunnen for selvmordet nøstes opp, sammen med mange enkeltheter fra besteforeldrenes begivenhetsrike liv, gripes jeg ikke av fortellingen. Dette kan i hvert fall delvis skyldes at fremstillingen blir for journalistisk og knapp, men noe av forklaringen er antakelig også at forfatteren ikke klarer å løfte frem de allmennmenneskelige aspektene ved sine besteforeldres historie. Til døden skiller oss ad blir derfor til en viss grad stående som en privat fortelling, et barnebarns forsøk på å finne ut mer om sine besteforeldres liv og død. Den er slett ikke dårlig, men den kunne vært mye bedre.

Trygve Holmøy

Nevrologisk avdeling

Akershus universitetssykehus 